\title{
Controlled Oxygen Therapy in Respiratory Failure*
}

\author{
D. C. S. HUTCHISON, M.A., B.M., B.CH. ; D. C. FLENLEY, M.B., CH.B., B.SC., M.R.C.P.ED. \\ K. W. DONALD, D.S.C., M.A., M.D., D.SC., F.R.C.P., F.R.C.P.ED., F.R.S.ED.
}

Brit. med. F., 1964, 2, 1159-1166

One of the most common medical emergencies in this country is the development of acute respiratory failure in patients with chronic generalized obstructive lung disease who suffer an acute pulmonary infection or develop further serious airway obstruction due to asthma, smog-irritation, or exacerbation of bronchitis. Hypoxia may be profound during these episodes, and its relief by the administration of oxygen is urgently necessary. However, this often leads to further depression of ventilation and the development of "carbon-dioxide narcosis" (Donald, 1949 ; Comroe, Bahnson, and Coates, 1950 ; Westlake, Simpson, and Kaye, 1955 ; Sieker and Hickam, 1956). The therapeutic problem in these patients is to relieve the hypoxia without producing a dangerous rise in arterial carbon dioxide tension $\left(\mathrm{PCO}_{2}\right)$.

Barach (1938) was the first to report the onset of mental changes following oxygen therapy. He suggested that oxygen should initially be given at fairly low concentrations and be gradually increased as the situation allowed. Donald (1953) suggested the administration of oxygen by tent (approximately $35-40 \%$ ) with intermittent brief periods breathing air. Campbell (1960a) elaborated Barach's original concept and suggested that the continuous administration of an oxygen mixture controlled with an accuracy of $\pm 1 \%$ in the range 24 to $35 \%$ would allow relief of hypoxaemia without running the risk of a serious rise in $\mathrm{PCO}_{2}$.

Other workers have favoured early tracheostomy and mechanical ventilation, but the difficulties of this approach could be avoided if control of the inspired-oxygen concentration alone could be shown to be a safe method of treatment in a large number of cases. Many questions, however, remain unanswered. It is not known whether hypoxaemia can be adequately relieved by this method without producing a dangerous rise in arterial $\mathrm{PCO}_{2}$ and fall in $p \mathrm{H}$, or whether an upper limit of $35 \%$ in the inspired-oxygen concentration will always prevent the $\mathrm{Po}_{2}$ from falling to a dangerous level. Likewise, it is not known what degree of control of the inspiredoxygen concentration is needed to prevent further $\mathrm{CO}_{2}$ retention. It is not known at what point of recovery accurate control can be discontinued and oxygen given at high concentrations. There are no reliable clinical criteria regarding when oxygen therapy can be discontinued altogether. Many workers have stressed the difficulty of predicting from the initial levels of $\mathrm{Po}_{2}, \mathrm{PCO}_{2}$, or $p \mathrm{H}$ how the patient will respond when given oxygen.

In the present study a number of patients have been treated by controlled oxygen administration without assisted ventilation, and an attempt has been made to answer some of the above questions. A working approach to the treatment of such patients by accurate control of the inspired-oxygen concentration is suggested.

Throughout the text the terms $\mathrm{Po}_{2}, \mathrm{PcO}_{2}$, and $p \mathrm{H}$ will refer to the $\mathrm{PO}_{2}$ and $\mathrm{PCO}_{2}(\mathrm{~mm} . \mathrm{Hg})$ and to the $\mathrm{pH}$ in the arterial blood, unless otherwise stated.

\section{Patients}

Nine patients suffering from acute respiratory failure were studied-one patient on two occasions. The clinical features in each case are summarized in Table $I$. On admission to hospital the haemoglobin ranged from 12.7 to $16.7 \mathrm{~g} . / 100 \mathrm{ml}$., with P.C.V. between 43 and $63 \%$, except in one patient (Case 7) who had an iron-deficiency anaemia with a haemoglobin of 9.5 g. $/ 100 \mathrm{ml}$. and P.C.V. of $37 \%$. The E.C.G. showed right-sided changes ( $P$ pulmonale, $R$ ventricular strain, partial R.B.B.B.) except in Case 5, where it was normal, and in Case 9, which showed evidence of an old myocardial infarction. Lung volumes were measured just before discharge from hospital (except in Case 7, who died). The vital capacity ranged from 0.8 to 2.3 litres. The ratio of residual volume to the total lung capacity varied between 58 and $82 \%$, the highest predicted normal value for these patients being $47 \%$. The F.E.V. $\cdot_{0.75}$ varied between 400 and $800 \mathrm{ml}$., with a mean of $590 \mathrm{ml}$. These results are all compatible with a diagnosis of chronic bronchitis and emphysema. The chest $x$-ray films satisfied the criteria of Laws and Heard (1962) for "emphysema" in all but two cases. In Case 3 cardiomegaly and pulmonary congestion were the only findings in the $x$-ray examination, and Case 5 showed generalized fine pulmonary fibrosis.

TABle I.-Clinical Condition of Patients on Admission

\begin{tabular}{|c|c|c|c|c|c|c|c|c|}
\hline \multirow{3}{*}{$\begin{array}{l}\text { Case } \\
\text { No. }\end{array}$} & \multirow{3}{*}{$\begin{array}{l}\text { Age } \\
\text { and } \\
\text { Sex }\end{array}$} & \multirow{2}{*}{\multicolumn{2}{|c|}{$\frac{\text { History }}{\text { Duration of }}$}} & \multicolumn{5}{|c|}{ Physical Examination } \\
\hline & & & & \multirow[b]{2}{*}{$\begin{array}{c}\text { Dys- } \\
\text { pnoeat }\end{array}$} & \multirow{2}{*}{$\begin{array}{l}\text { Finger- } \\
\text { club- } \\
\text { bing }\end{array}$} & \multirow{2}{*}{$\begin{array}{l}\text { Conges- } \\
\text { tive } \\
\text { Failure }\end{array}$} & \multirow{2}{*}{$\begin{array}{c}\text { Ausculta } \\
\text { tion of } \\
\text { Chest }\end{array}$} & \multirow{2}{*}{ B.P. } \\
\hline & & $\begin{array}{l}\text { Symp- } \\
\text { toms* } \\
\text { (Years) }\end{array}$ & $\begin{array}{l}\text { Present } \\
\text { Illness } \\
\text { (Days) }\end{array}$ & & & & & \\
\hline $\begin{array}{l}1 \\
2 \\
3 \\
4 \\
5 \\
6 \\
7 \\
8 \\
9\end{array}$ & $\mid \begin{array}{rl}69 & \mathrm{M} \\
56 & \mathrm{M} \\
56 & \mathrm{M} \\
58 & \mathrm{M} \\
59 & \mathrm{~F} \\
72 & \mathrm{~F} \\
39 & \mathrm{M} \\
63 & \mathrm{~F} \\
43 & \mathrm{M} \\
73 & \mathrm{~F}\end{array}$ & \begin{tabular}{|c|}
15 \\
8 \\
8 \\
6 \\
6 \\
Nil \\
3 \\
1 \\
7 \\
7 \\
15
\end{tabular} & $\begin{array}{r}3 \\
7 \\
4 \\
7 \\
7 \\
21 \\
14 \\
14 \\
7 \\
4\end{array}$ & $\begin{array}{l} \pm \\
+ \\
\pm \\
+ \\
+ \\
+ \\
+ \\
+\end{array}$ & $\begin{array}{l} \pm \\
\pm \\
\pm \\
\pm \\
\pm \\
=\end{array}$ & $\begin{array}{c} \pm \\
\overline{+} \\
++ \\
++ \\
\overline{-} \\
+ \pm \\
\pm\end{array}$ & $\begin{array}{c}\text { R.C. } \\
\text { D. } \\
\text { D. } \\
\text { R.C. } \\
\text { R. } \\
\text { D.R. } \\
\text { R. } \\
\text { R. } \\
\text { R. } \\
\text { R.C. }\end{array}$ & $\begin{array}{l}150 / 80 \\
180 / 90 \\
140 / 80 \\
140 / 100 \\
150 / 80 \\
120 / 60 \\
180 / 50 \\
160 / 80 \\
150 / 90\end{array}$ \\
\hline
\end{tabular}

* Winter cough, sputum, and dyspnoea; + Tachypnoea and use of accessory muscles. $R=$ Rhonchi. $C=$ Crepitations. $D=$ Diminished breath sounds. ₹Con oedema; $++++=$ above + hepatomegaly.

\section{Plan of Study}

The patient's response to variations in the concentration of inspired oxygen was examined in detail, giving a total of 10 studies since Case 2 was studied during the two separate episodes. Arterial blood samples were taken from a small indwelling nylon catheter introduced into the brachial or radial artery by the Seldinger technique, thus avoiding repeated arterial puncture (Bernéus, Carlsten, Holmgren, and Seldinger, 1954); the $\mathrm{Po}_{2}, \mathrm{PCO}_{2}$, and $p \mathrm{H}$ of each sample were estimated. The catheter lumen was kept filled with a heparin solution, and a tap closed off the system between the periods of sampling.

In all but one of these 10 studies (Case 5) the catheter was introduced shortly after admission and either two or three arterial blood samples were taken during a period of 20 to 30 minutes while the patient was breathing air, before oxygen or any other treatment had been given. Following this, oxygen was adminis-

* From the Department of Medicine, University of Edinburgh, at the Royal Infirmary, Edinburgh. 
tered, in Case 1 by the Venturi mask (Campbell, 1960b), and in subsequent studies by a blower system of our own design (Flenley, Hutchison, and Donald, 1963) which was capable of controlling the inspired-oxygen concentration with an accuracy of $\pm 1.8 \%$ (95\% confidence limits). After the initial period of air-breathing, the inspired-oxygen concentration was increased to $30-35 \%$ and maintained at this level during the next hour. The exact inspired-oxygen concentration was determined by analysis of an inspiratory sample from the oxygen mask of the blower system. If the $\mathrm{PCO}_{2}$ rose by more than $6 \mathrm{~mm}$. $\mathrm{Hg}$ the oxygen concentration was reduced in the next hour, but if the rise in $\mathrm{PCO}_{2}$ was less than $6 \mathrm{~mm}$. $\mathrm{Hg}$ the inspired-oxygen concentration was increased. This routine was followed in most cases, but the exact procedure varied from case to case as shown in Table II. In some cases the blood gases were

\begin{tabular}{|c|c|c|c|c|c|c|c|}
\hline \multicolumn{8}{|c|}{ TABLE II } \\
\hline \multirow{2}{*}{$\begin{array}{l}\text { Case and } \\
\text { Day of } \\
\text { Study }\end{array}$} & \multirow[b]{2}{*}{ Hours } & \multirow{2}{*}{$\begin{array}{c}\text { Inspired } \\
\mathrm{O}_{2} \text { Conc. } \\
\%\end{array}$} & \multicolumn{5}{|c|}{ Arterial Blood } \\
\hline & & & $\begin{array}{c}\mathrm{Po}_{2} \\
\mathrm{~mm} . \mathrm{Hg}\end{array}$ & $\begin{array}{c}\mathrm{PcO}_{2} \\
\mathrm{~mm} . \mathrm{Hg}\end{array}$ & $p \mathrm{H}$ & $\underset{\%}{\mathrm{So}_{2}}$ & $\begin{array}{c}\text { Buffer } \\
\text { Base } \\
\mathrm{mEq} / \mathrm{l} .\end{array}$ \\
\hline $\begin{array}{l}\text { Case } 1 \\
\text { Day } 1 \text { (acute) }\end{array}$ & $\begin{array}{c}0 \\
1 \\
1 \\
12 \\
2 ! \\
2 !\end{array}$ & $\begin{array}{c}20 \cdot 9 \\
V=31 \\
V=27 \\
V=23 \\
20 \cdot 9 \\
20 \cdot 9 \\
\end{array}$ & $\begin{array}{l}36 \\
38 \\
69 \\
70 \\
65 \\
65 \\
58 \\
61 \\
43 \\
42 \\
59\end{array}$ & $\begin{array}{l}\frac{72}{68} \\
\frac{63}{57} \\
\frac{53}{47} \\
\frac{47}{2}\end{array}$ & $\begin{array}{l}7 \cdot 33 \\
7 \cdot 36 \\
7 \cdot 38 \\
7 \cdot 38 \\
7 \cdot 38 \\
7 \cdot .40 \\
\overline{7 \cdot 43} \\
7 \cdot 38\end{array}$ & $\begin{array}{l}\frac{64}{69} \\
92 \\
\frac{91}{91} \\
90 \\
79 \\
89\end{array}$ & $\begin{array}{l}\frac{55}{55} \\
\frac{56}{54} \\
\frac{54}{50}\end{array}$ \\
\hline $\begin{array}{l}\text { Case } 2 \\
\quad \text { Study 1) } \\
\text { Day } 1 \text { (acute) }\end{array}$ & $\begin{array}{l}0 \\
11 \\
11 \\
3 \\
3 ! \\
5 \\
5 ! \\
6 \\
6 !\end{array}$ & $\begin{array}{l}20 \cdot 9 \\
36 \cdot 4 \\
29 \cdot 2 \\
27 \cdot 4 \\
46 \cdot 0 \\
20 \cdot 9 \\
52 \cdot 6 \\
\end{array}$ & $\begin{array}{r}23 \\
26 \\
46 \\
56 \\
48 \\
48 \\
42 \\
40 \\
92 \\
97 \\
46 \\
156 \\
\end{array}$ & $\begin{array}{l}79 \\
86 \\
90 \\
93 \\
77 \\
75 \\
78 \\
71 \\
78 \\
78 \\
72 \\
94 \\
\end{array}$ & $\begin{array}{l}7.32 \\
7.28 \\
7.25 \\
7.24 \\
7.41 \\
7.29 \\
7.30 \\
7.33 \\
7.36 \\
7.33 \\
7.35 \\
7.25 \\
\end{array}$ & $\begin{array}{l}38 \\
42 \\
74 \\
82 \\
79 \\
78 \\
72 \\
71 \\
96 \\
96 \\
79 \\
99 \\
\end{array}$ & $\begin{array}{l}56 \\
54 \\
55 \\
54 \\
56 \\
54 \\
55 \\
55 \\
62 \\
58 \\
57 \\
58 \\
\end{array}$ \\
\hline $\begin{array}{l}\text { Case } 2 \\
\quad \text { (Study 2) } . \\
\text { Day 1 (acute) }\end{array}$ & $\begin{array}{c}0 \\
13 \\
1 \\
1 \frac{13}{2} \\
2 \\
2 \frac{1}{2} \\
3 \frac{3}{1} \\
4 \\
17 \frac{1}{2}\end{array}$ & $\begin{array}{r}40.0 \\
20.9 \\
20.9 \\
\end{array}$ & $\begin{array}{l}33 \\
34 \\
31 \\
61 \\
66 \\
69 \\
46 \\
56 \\
60 \\
45 \\
44 \\
45 \\
71 \\
71 \\
66 \\
93 \\
95 \\
90 \\
34 \\
36 \\
38 \\
67 \\
\end{array}$ & $\begin{array}{l}71 \\
72 \\
73 \\
82 \\
83 \\
75 \\
81 \\
81 \\
82 \\
74 \\
79 \\
70 \\
70 \\
70 \\
72 \\
73 \\
74 \\
68 \\
67 \\
67 \\
45 \\
\end{array}$ & $\begin{array}{l}7.39 \\
7.38 \\
7.33 \\
7.32 \\
7.31 \\
7.34 \\
7.33 \\
7.33 \\
7.36 \\
7.35 \\
7.35 \\
7.38 \\
7.38 \\
7.37 \\
7.35 \\
7.41 \\
7.39 \\
7.39 \\
-\end{array}$ & $\begin{array}{l}64 \\
64 \\
88 \\
90 \\
93 \\
81 \\
85 \\
88 \\
78 \\
78 \\
78 \\
93 \\
97 \\
97 \\
96 \\
65 \\
69 \\
72 \\
91 \\
\end{array}$ & $\begin{array}{l}61 \\
61 \\
60 \\
60 \\
58 \\
60 \\
60 \\
63 \\
58 \\
60 \\
60 \\
61 \\
61 \\
60 \\
61 \\
59 \\
59 \\
\end{array}$ \\
\hline $\begin{array}{l}\text { Case } 3 \\
\text { Day } 1 \text { (acuite) }\end{array}$ & $\begin{array}{l}0 \\
11 \\
1 \frac{1}{1} \\
2 \frac{3}{3} \\
3 \\
3 \\
4 \\
4 \frac{3}{3} \\
6^{2}\end{array}$ & $\begin{array}{l}20 \cdot 9 \\
36 \cdot 0 \\
29 \cdot 9 \\
24 \cdot 4 \\
29 \cdot 5 \\
20 \cdot 9 \\
\end{array}$ & $\begin{array}{l}39 \\
40 \\
67 \\
74 \\
54 \\
59 \\
45 \\
49 \\
52 \\
60\end{array}$ & $\begin{array}{r}100 \\
93 \\
115 \\
118 \\
122 \\
118 \\
107 \\
107 \\
103 \\
62\end{array}$ & $\begin{array}{l}7.35 \\
7.35 \\
7.33 \\
7.23 \\
7.25 \\
7.25 \\
7.25 \\
7.34 \\
7.34\end{array}$ & $\begin{array}{l}71 \\
72 \\
90 \\
81 \\
84 \\
73 \\
77 \\
83 \\
88\end{array}$ & $\begin{array}{l}73 \\
68 \\
76 \\
66 \\
67 \\
61 \\
61 \\
72 \\
54\end{array}$ \\
\hline $\begin{array}{ll}\text { Day 2 } & . \\
\text { Day 3 } & . \\
\text { Day 4 } & . \\
\text { Day 5 } & . . \\
\end{array}$ & $\begin{array}{l}0 \\
1 \\
2 \\
2 \frac{1}{4} \\
44 \\
43\end{array}$ & $\begin{array}{c}20 \cdot 9 \\
34.5 \\
42 \cdot 0 \\
\text { Polymask } \\
V=29 \\
V=29 \\
V=29\end{array}$ & $\begin{array}{l}39 \\
40 \\
74 \\
79 \\
81 \\
87 \\
78 \\
57 \\
56 \\
60\end{array}$ & $\begin{array}{l}58 \\
58 \\
62 \\
64 \\
61 \\
63 \\
77 \\
59 \\
59 \\
57\end{array}$ & $\begin{array}{l}7.43 \\
7.43 \\
7.39 \\
7.38 \\
7.42 \\
7.38 \\
7.26 \\
7.42 \\
7.41 \\
7.39\end{array}$ & $\begin{array}{l}75 \\
76 \\
94 \\
95 \\
95 \\
96 \\
92 \\
89 \\
89 \\
88\end{array}$ & $\begin{array}{l}57 \\
57 \\
57 \\
57 \\
59 \\
57 \\
52 \\
58 \\
58 \\
56\end{array}$ \\
\hline $\begin{array}{ll}\text { Day } 2 & \\
\text { Day 3 } & . \\
\text { Day 3 } & . \\
\text { Day 4 } & . \\
\text { Day 6 } & .\end{array}$ & $\begin{array}{l}0 \\
2 \\
2 \\
2 \frac{1}{2} \\
4_{2}^{\frac{1}{2}} \\
6 \\
7\end{array}$ & $\begin{array}{c}\text { Polymask } \\
28.9 \\
29.5 \\
32.2 \\
32.5 \\
\text { Polymask } \\
28.7 \\
30.1\end{array}$ & $\begin{array}{r}1 \overline{14} \\
47 \\
52 \\
52 \\
53 \\
62 \\
57 \\
67 \\
53 \\
56 \\
63\end{array}$ & $\begin{array}{l}86 \\
90 \\
86 \\
77 \\
65 \\
65 \\
65 \\
64 \\
71 \\
57 \\
65 \\
63\end{array}$ & $\begin{array}{l}7.28 \\
7 \cdot 27 \\
7.34 \\
7.38 \\
7 \cdot 39 \\
7.44 \\
7.45 \\
7.38 \\
7.44 \\
7.40 \\
7.39\end{array}$ & $\begin{array}{l}97 \\
79 \\
84 \\
86 \\
92 \\
89 \\
92 \\
87 \\
87 \\
90\end{array}$ & $\begin{array}{l}58 \\
58 \\
63 \\
63 \\
59 \\
64 \\
64 \\
62 \\
59 \\
60 \\
58\end{array}$ \\
\hline
\end{tabular}

estimated on a number of days after the "acute study," and, where possible, estimations were carried out when the patient had recovered from the acute infection (Table II). Lung volumes were also measured at this time.

\section{Laboratory Methods}

Arterial blood carbon dioxide tension was estimated with a Severinghaus electrode (Severinghaus and Bradley, 1958). Arterial blood oxvgen tension was estimated with a Clark cell (Bishop and Pincock, 1959) and $p \mathrm{H}$ with a glass electrode (Electronic Instruments Ltd.). Arterial oxygen saturation was derived from the line-chart of Severinghaus (1958) and bufferbase from the nomogram of Singer and Hastings (1948). Estimations were carried out as soon as possible after the samples had been withdrawn, and in any case within 20 minutes.

The oxygen concentration in the samples of inspired gas was measured with the Clark cell by a method already described (Flenley et al., 1963).

The total lung capacity and its subdivisions were measured by the closed-circuit helium-dilution method (Meneely and

TABLE II.-(Contd.)

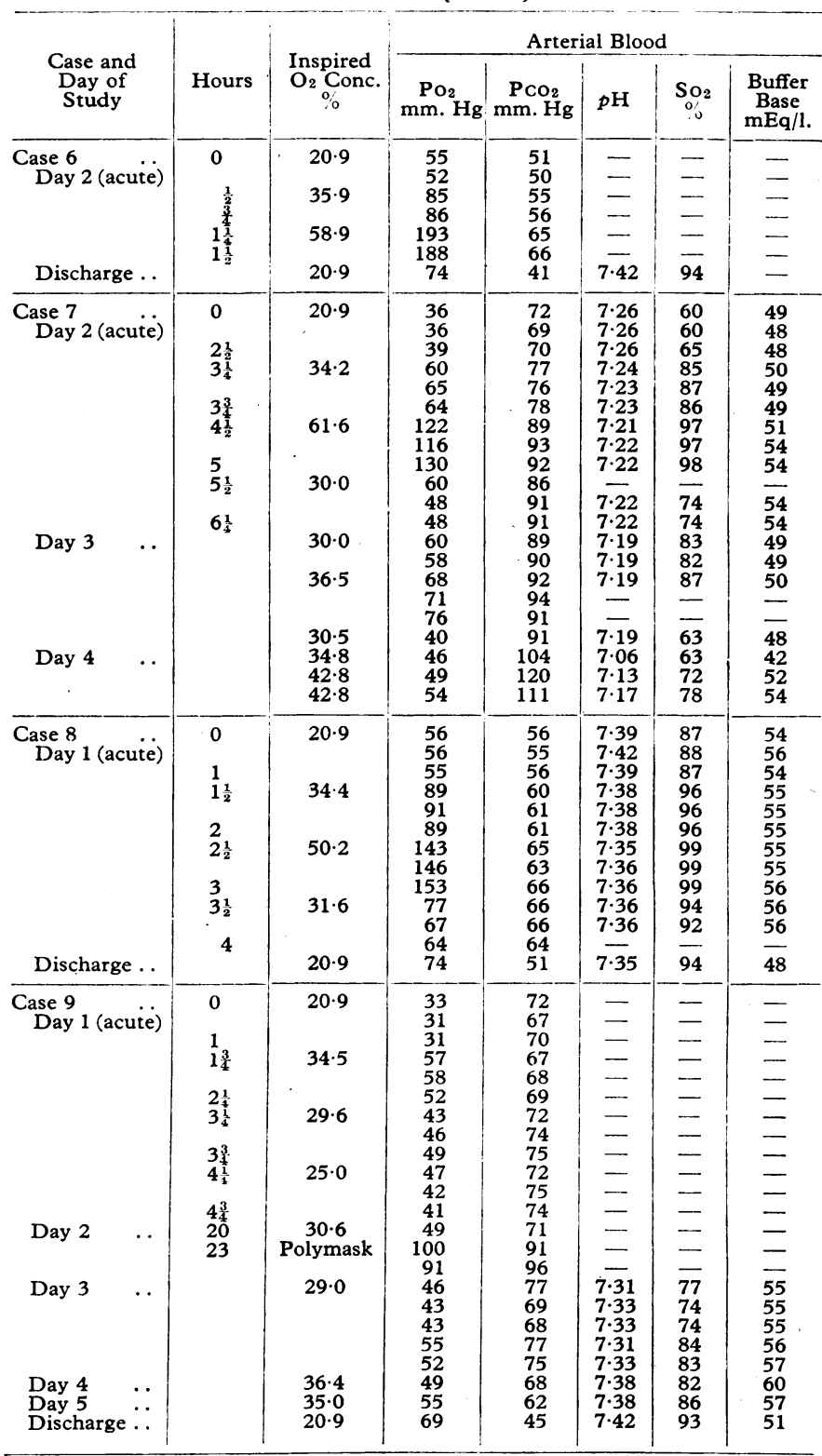


Kaltreider, 1941). The 0.75 -second fast expiratory volume (F.E.V. ${ }_{0.75}$ ) was measured with a Bernstein spirometer. Normal values were obtained from the simplified equations of Needham, Rogan, and McDonald (1954).

\section{Results}

The values of the arterial blood $\mathrm{Po}_{2}, \mathrm{PcO}_{2}$, and $\mathrm{pH}$, at the various concentrations of inspired oxygen, are shown in detail in Table II together with the derived oxygen saturations $\left(\mathrm{So}_{2}\right)$ and buffer-base values.

All patients had a raised $\mathrm{PCO}_{2}$ and decreased $\mathrm{Po}_{2}$ when breathing air at the start of the studies. The $p H$ was below normal in five of the seven studies in which measurements were made. during the initial phase of air-breathing.

Cases $1,4,5,6$, and 8 suffered from moderate respiratory failure, but their condition during treatment did not cause anxiety and they all survived. Cases 2,3 , and 9 were in more severe respiratory failure; all were gravely ill on admission and the outcome of treatment was uncertain for some days, but they all recovered. One patient (Case 7) died from respiratory failure with progressive acidosis. The clinical progress of each case is summarized below.

\section{Clinical Progress}

Case 1 (Fig. 1).- This man was comatose when breathing air, with severe hypoxaemia $\left(\mathrm{Po}_{2} 36\right)$ and hypercapnia $\left(\mathrm{PCO}_{2} 72\right)$, and a $p \mathrm{H}$ of 7.33. He responded rapidly to oxygen given by the Venturi mask, with a persistent fall in $\mathrm{PCO}_{2}$ from 70 to 53 , irrespective of the inspired-oxygen concentration.

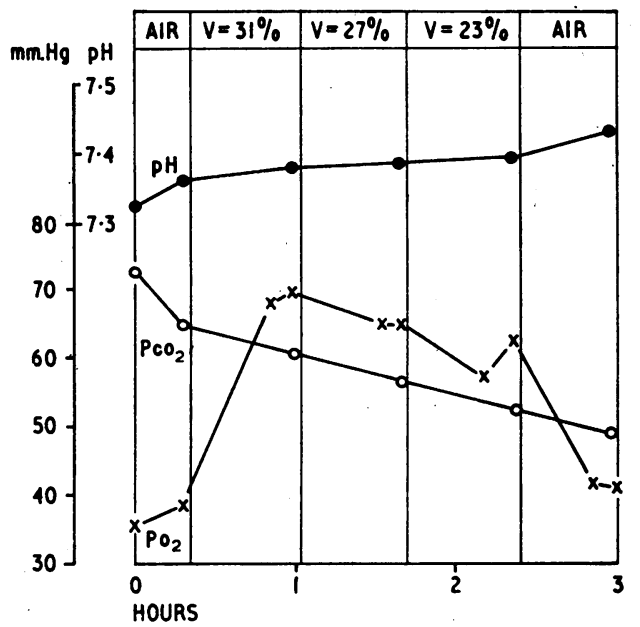

FIG. 1.-Arterial carbon dioxide tension $\left(\mathrm{PCO}_{2}\right)$, arterial $\mathrm{pH}$, and arterial oxygen tension $\left(\mathrm{PO}_{2}\right)$ in Case 1 , breathing air and during early stages of oxygen therapy. Oxygen was given by the Venturi oxygen therapy. Oxygen was given by the Venturi
mask, $\mathrm{V}=31$, being the Venturi gauge set at $31 \%$ oxygen.

Case 2, Study 1 (Fig. 2).-This patient was unconscious on admission with profound hypoxaemia while breathing air $\mathrm{Po}_{2} 26$, and considerable carbon-dioxide retention and acidosis $\left(\mathrm{PCO}_{2} 86\right.$, pH 7.28). The hypoxaemia was partially relieved $\left(\mathrm{Po}_{2} 56\right)$ by administration of $36 \%$ oxygen, but this led to a further rise in $\mathrm{PCO}_{2}$ to 93 and a fall in $\mathrm{pH}$ to 7.24. The inspired oxygen concentration was then reduced in two stages to $27 \%$, leading to a fall in $\mathrm{PCO}_{2}$, but only at the expense of persistent severe hypoxaemia $\left(\mathrm{Po}_{2} 40\right)$. However, after six hours of controlled oxygen therapy he could tolerate $46 \%$ oxygen with no further increase in $\mathrm{PCO}_{2}$ and a near normal $\mathrm{pH}$. The next day his $\mathrm{Po}_{2}$ was only 46 while breathing air and his $\mathrm{PCO}_{2}$ rose to $94(\mathrm{pH} 7.25)$ while breathing $53 \%$ oxygen $\left(\mathrm{Po}_{2}\right.$ 156). This respiratory acidosis was reversed once more by giving a lower concentration of oxygen, and he finally recovered.

Case 2, Study 2.-This was carried out during a further attack 18 months later. When breathing air he had less severe hypoxaemia
$\left(\mathrm{Po}_{2}\right.$ 33) and a $\mathrm{PcO}_{2}$ of 72 but a normal $\mathrm{pH}$. The $\mathrm{PcO}_{2}$ rose by 10 with $34 \%$ oxygen, but this rise was not readily reversed when $30 \%$ and $25 \%$ oxygen were substituted. However, owing to the presence of a high buffer base the $\mathrm{pH}$ never fell below 7.31. One day later he could tolerate $40 \%$ oxygen with little rise in $\mathrm{PCO}_{2}$. He again recovered.

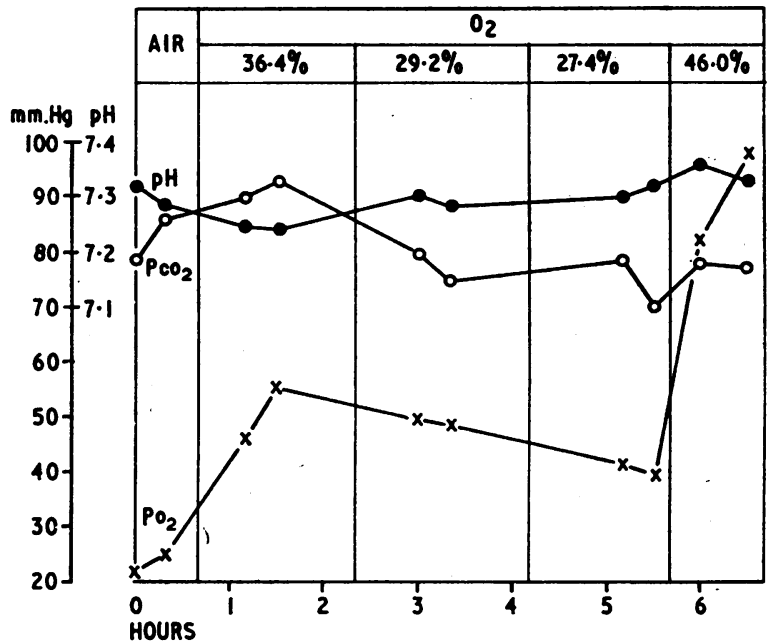

Fig. 2.-Arterial $\mathrm{Pco}_{2}, \mathrm{pH}$, and $\mathrm{Po}_{2}$ in Case 2, Study 1, when breathing air and during the early stages of controlled oxygen treatment. Oxygen concentrations in the inspired gas are also shown.

Case 3 (Fig. 3).-This patient with marked congestive failure had moderate hypoxaemia $\left(\mathrm{Po}_{2} \cdot 40\right)$, with a $\mathrm{PCO}_{2}$ of 100 . As the buffer base was also very high $(73-68 \mathrm{mEq} / \mathrm{l}$.) the $p \mathrm{H}$ was no lower than 7.35 when he was breathing air. A further serious rise of $\mathrm{PCO}_{2}$ developed with $36 \%$ oxygen, and this rise was not reversed until $24 \%$ oxygen was given. $\mathrm{He}$ later tolerated $30 \%$ oxygen $\left(\mathrm{Po}_{2}\right.$ 52) without further rise in $\mathrm{PCO}_{2}$ and survived the episode.

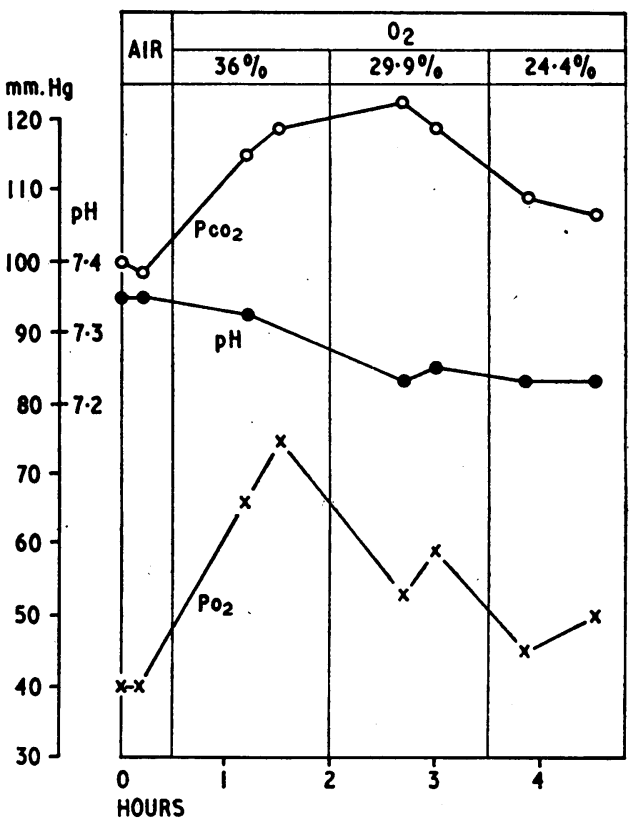

FIG. 3.-Arterial $\mathrm{PCO}_{2}, p \mathrm{H}$, and $\mathrm{PO}_{2}$ in Case 3 when breathing air and during the early stages of controlled oxygen therapy. Oxygen concentrations in the inspired gas are also shown.

Case 4.-This woman was hypoxaemic $\left(\mathrm{Po}_{2} 40\right)$, with moderate carbon-dioxide retention $\left(\mathrm{PCO}_{2} 58\right)$ and a normal $\mathrm{pH}$. No important rise in $\mathrm{PCO}_{2}$ developed on $35 \%$ oxygen or $42 \%$ oxygen. For this reason oxygen was given by the Polymask for the next 24 hours. $\mathrm{PCO}_{2}$ had risen by 15 at the end of this time with a severe fall in $\mathrm{pH}$ to 7.26. She was then given oxygen by the Venturi mask set at $29 \%\left(\mathrm{Po}_{2}\right.$ 57), the $\mathrm{PcO}_{2}$ falling to 57 , and she recovered without further incident. 
Case 5.-As this woman had no history of chronic bronchitis she was initially treated with oxygen by Polymask. Twenty-four hours of this treatment $\left(\mathrm{Po}_{2}\right.$ 114) produced coma, with a $\mathrm{PcO}_{2}$ of 90 and a $p \mathrm{H}$ of 7.28. Carbon-dioxide retention improved slowly after the inspired oxygen was reduced to $29.5 \%$ and $32 \%$, with the $p \mathrm{H}$ increasing to 7.44 as the $\mathrm{PCO}_{2}$ fell to 65 . Chest $x$-ray examination on recovery showed evidence of generalized fine pulmonary fibrosis.

Case 6.-This man had mild hypoxaemia $\left(\mathrm{Po}_{2}\right.$ 54) and carbondioxide retention $\left(\mathrm{PcO}_{2} 50\right)$, with an increase in $\mathrm{PCO}_{2}$ to 66 as $59 \%$ oxygen was given ; this rise was reversed with lower levels of oxygen and he recovered.

Case 7 (Fig. 4).-This woman was grossly obese, uraemic (blood urea $200 \mathrm{mg} . / 100 \mathrm{ml}$.), in severe congestive heart failure, and was also suffering from iron-deficiency anaemia ( $\mathrm{Hb} 9.5 \mathrm{~g} . / 100 \mathrm{ml}$.). She was hypoxaemic $\left(\mathrm{Po}_{2} 36\right)$ and hypercapnic $\left(\mathrm{PCO}_{2} 70\right)$, with a $\mathrm{pH}$ of 7.26 , when breathing air. After breathing $34 \%$ oxygen her $\mathrm{PO}_{2}$ rose to 65 , with a rise of $6 \mathrm{~mm}$. $\mathrm{Hg}$ in $\mathrm{PCO}_{2} ; 62 \%$ oxygen caused a serious rise of $\mathrm{PcO}_{2}$ to 93 , the $p \mathrm{H}$ falling to 7.22 . This rise in $\mathrm{PCO}_{2}$ was not reversed by lowering the inspired oxygen to $30 \%$, and the $p \mathrm{H}$ continued to fall to 7.06 , the $\mathrm{PCO}_{2}$ being 104 . Sodium lactate intravenously increased the $p \mathrm{H}$ to only 7.17 and she died shortly afterwards. Throughout the three days of her stay in hospital she remained in severe heart failure, with marked skinvasodilatation, and a blood-pressure of $180 / 60$. Necropsy showed bilateral apical fibrosis and emphysema, lower-lobe oedema, and patent major airways. There was right ventricular hypertrophy and the kidneys were congested but otherwise normal.

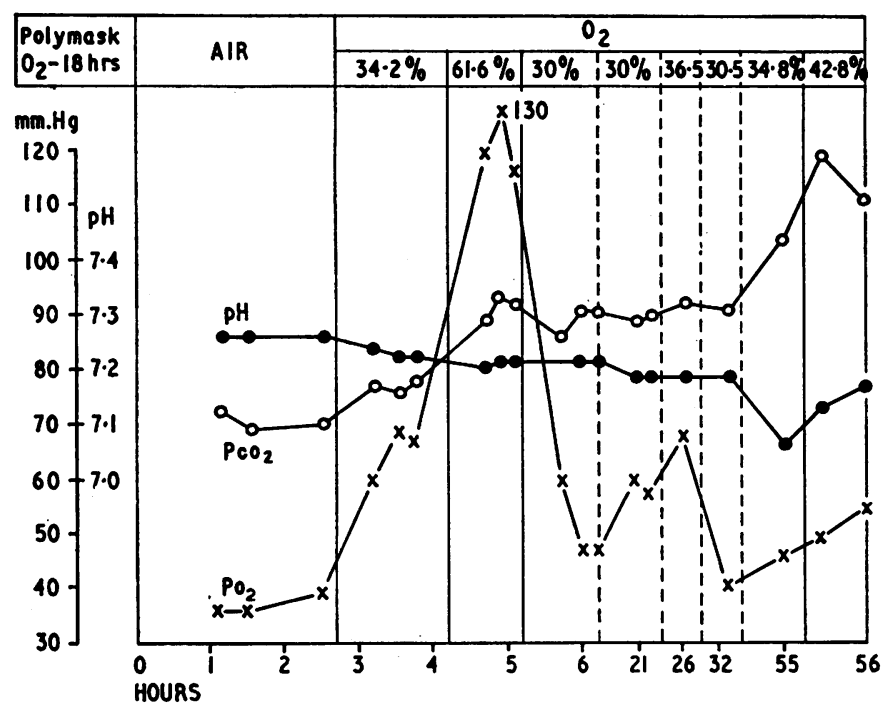

FIG. 4.-Arterial $\mathrm{PCO}_{y}, \mathrm{pH}$, and $\mathrm{Po}_{2}$ in Case 7 when breathing air and during controlled oxygen therapy. Oxygen concentrations in the inspired gas are also shown.

Case 8.- In this man the $\mathrm{Po}_{2}$ was 56 and $\mathrm{PcO}_{2} 56$ when breathing air. The $\mathrm{PcO}_{2}$ rose to 66 when $50 \%$ oxygen was given and the $\mathrm{pH}$ dropped to 7.36 ; he was maintained in a satisfactory condition on a lower level of inspired oxygen (32\%) and soon recovered.

Case 9.- This woman was in severe respiratory. failure with an initial $\mathrm{Po}_{2}$ of 33 and $\mathrm{PcO}_{2}$ of 72 when breathing air, but $p \mathrm{H}$ estimations were not available for the first day. The $\mathbf{P C O}_{2}$ showed little rise with $35 \%$ to $25 \%$ oxygen, but when oxygen was given by the Polymask, producing a $\mathrm{Po}_{2}$ of 100 , the $\mathrm{PcO}_{2}$ rose to 91 . This rise in $\mathrm{PCO}_{2}$ was slowly reversed when $29 \%$ oxygen was given.

In the introduction various questions of the control of oxygen therapy were posed. An attempt is made to provide answers to these questions from the results in Table II.

\section{Can Hypoxia be Relieved Without a Dangerous Rise in $\mathrm{PCO}_{2}$ or Fall in $\mathbf{~ p H}$ ?}

It is proposed later that a $\mathrm{Po}_{2}$ of 50 will prevent death from hypoxia, and that the $p \mathrm{H}$ should be maintained above 7.25 during therapy (see Discussion). In Case 1 there was no danger of the $p \mathrm{H}$ falling below 7.25 irrespective of the level of $\mathrm{PO}_{2}$ (between 58 and 70). In Case 2 (Study 1, Fig. 2) the above criteria could not be completely achieved, but a $\mathrm{Po}_{2}$ of 48 was obtained with a $p \mathrm{H}$ of 7.29 when breathing $29 \%$ oxygen. In Case 2 (Study 2) administration of $34 \%$ oxygen kept the $\mathrm{Po}_{2}$ above 50 and the $p H$ between 7.31 and 7.33. Case 3 (Fig. 3) illustrates that increasing carbon-dioxide retention $\left(\mathrm{PCO}_{2}\right.$ rising from 100 to 122 ) on oxygen therapy could be reversed only by lowering the $\mathrm{Po}_{2}$ to 45 (24\% oxygen required), when the $p \mathrm{H}$ was 7.25. Our criteria of $\mathrm{Po}_{2}$ over 50 and $p \mathrm{H}$ over 7.25 were therefore not satisfied in this case. Values obtained in Case 7 also failed to meet these criteria, and artificial ventilation would have been started earlier if the scheme of treatment which is proposed later had been adopted. Case 9 shows that a rise in $\mathrm{PCO}_{2}$ from 70 to 75 could be reversed only by lowering the $\mathrm{Po}_{2}$ to 47 and subsequently to 41 , but unfortunately $\mathrm{pH}$ measurements were not available during the first day's treatment.

Controlled oxygen therapy therefore failed to provide a $\mathrm{Po}_{2}$ over 50 and a $p H$ over 7.25 in three of the 10 studies.

\section{Is it Safe to Assume that an Inspired Oxygen Concentration of $\mathbf{3 5} \%$ will Always Prevent a Dangerous Level of Hypoxaemia in These Patients?}

Again a $\mathrm{Po}_{2}$ of 50 is proposed as the minimum safe level (see Discussion). An inspired-oxygen concentration of $35 \%$ $( \pm 1 \%)$ failed to produce a $\mathrm{Po}_{2}$ over 50 in Cases 2, 7, and 9.

\section{Do Moderate Changes (5\%) in Inspired-oxygen Concentration in the Range $21-35 \%$ Produce Changes in Carbon-dioxide Retention?}

In Case 2 (Study 1, Fig. 2) lowering the inspired-oxygen concentration from $36 \%$ to $29 \%$ produced a fall in $\mathrm{PCO}_{2}$ from 93 to 77 , and a further decrease to $27 \%$ oxygen caused the $\mathrm{PCO}_{2}$ to fall to 71 with a further rise in $p \mathrm{H}$ to 7.33 . In Case 3 (Fig. 3) lowering the inspired oxyger from 30 to $24 \%$ was necessary to reverse a progressive rise in $\mathrm{PCO}_{2}$. These two cases are the only ones where changes of about $5 \%$ in oxygen concentration are shown to have caused significant changes in $\mathrm{PCO}_{2}$.

\section{At What Stage of Recovery from Acute Respiratory Failure can Uncontrolled High Concentrations of Oxygen be Substituted?}

Case 1 (Fig. 1) was given oxygen by the Venturi mask at various settings, and over the course of two hours $\mathrm{PcO}_{2}$ fell irrespective of the setting of the Venturi gauges (Table II). Case 2 (Study 1) developed a serious rise in $\mathrm{PcO}_{2}$ to $94(p \mathrm{H}$ 7.25 ) when given $52 \%$ oxygen after 24 hours' controlled oxygen therapy. This rise in $\mathrm{PcO}_{2}$ was reversed by reducing the inspired-oxygen concentration. In Case 2 (Study 2) breathing $40 \%$ oxygen produced a rise in $\mathrm{PCO}_{2}$ on the second day, the $\mathrm{pH}$ falling to 7.35 , and this trend was reversed when breathing air. Case 4, who suffered from moderate respiratory failure $\left(\mathrm{PCO}_{2} 58\right)$ and tolerated $42 \%$ oxygen with no exacerbation of acidosis, nevertheless developed a $\mathrm{pH}$ of 7.26 and $\mathrm{PCO}_{2}$ of 77 when the Polymask was used the day after admission. Case 5, who developed carbon-dioxide narcosis when breathing from a Polymask initially, showed a rise in $\mathrm{PCO}_{2}$ from 64 to 71 when a Polymask was used a second time three days later. Case 7 (Fig. 4) showed a marked rise in $\mathrm{PCO}_{2}$ from 78 to 93 when $62 \%$ oxygen was injudiciously given on the first day, and this rise could not be reversed when the oxygen concentration was reduced. In Case 9 a rise in $\mathrm{PcO}_{2}$ from 71 to 91 occurred when a Polymask was used on the second day.

It can be concluded that high concentrations of oxygen, as produced by the Polymask when set at $61 . / \mathrm{min}$. (approximately 
$60 \%$ oxygen, Flenley et al., 1963), can cause serious exacerbations of carbon-dioxide retention for at least three days after the start of carefully controlled treatment of an acute episode of respiratory failure.

\section{When Can Oxygen Therapy be Discontinued ?}

Case 2 (Study 1) developed a $\mathrm{Po}_{2}$ of 46 when breathing air after two days in hospital, and in Study 2 the $\mathrm{Po}_{2}$ fell to 34 when breathing air on the second day. Case 4 had a $\mathrm{Po}_{2}$ of only 60 when breathing $29 \%$ oxygen from the Venturi apparatus five days after admission. Case 5 showed similar figures on the sixth day. Case 9 had a $\mathrm{Po}_{2}$ of only 55 when receiving $35 \%$ oxygen on the fifth day.

In the light of these results controlled oxygen therapy may be required for at least one week, if not longer, in this type of case.

\section{Discussion}

The reasons for the onset of ventilatory depression during acute exacerbations of chronic bronchitis are not fully understood. According to one school of thought the most important factor is depression and abnormal behaviour of the respiratory centre, in addition to impairment of the function of the lungs themselves. An alternative view is that the respiratory centre is behaving normally, but that the increased airways obstruction associated with the acute infection leads to such an increase in the mechanical work of breathing that failure of the respiratory muscles themselves takes place, leading to underventilation. However respiratory failure is produced, hypoxia appears to be of increasing importance as a stimulus to respiration, and the syndrome of underventilation and carbon-dioxide narcosis following oxygen therapy is well recognized. There is considerable patient-to-patient difference in the response to oxygen therapy, and Comroe et al. (1950) were the first of a number of groups of investigators to stress the difficulty of predicting from the initial $\mathrm{PCO}_{2}, \mathrm{PO}_{2}$, or $p \mathrm{H}$ which patients would develop respiratory depression. We have attempted to elucidate some of the causes of this uncertainty and also to assess the relative importance of the actual level of arterial $\mathrm{PCO}_{2}, \mathrm{Po}_{2}$, and $p \mathrm{H}$.

\section{Control of Inspired Oxygen Concentration}

The magnitude of the increase in $\mathrm{Po}_{2}$ must be one of the most important factors in bringing about ventilatory depression during oxygen therapy. Even with modern methods of oxygen therapy there is still considerable uncertainty regarding the true inspired-oxygen concentration, and for this reason a blower system previously described (Flenley et al., 1963) was used in the majority of the studies reported here. This system was shown to deliver an inspired-oxygen concentration which was predictable within $\pm 1.8 \%$ (95\% confidence limits) and to be capable of maintaining this in the face of a respiratory minutevolume of up to 10 litres per minute. It was then possible to study the patient's response to a precise inspired-oxygen concentration and to maintain this concentration for long periods.

\section{Relation Between the Inspired-oxygen Concentration and the Arterial Oxygen Tension}

The relation between the inspired-oxygen concentration $\left(\mathrm{FIO}_{2} \%\right)$ and the arterial $\mathrm{Po}_{2}$ is shown in Fig. 5 ; for the sake of comparison between patients $\mathrm{FIo}_{2} \%$ has been plotted against the increment in $\mathrm{Po}_{2}\left(\Delta \mathrm{Po}_{2}\right)$ rather than the absolute values of $\mathrm{Po}_{2}$. The appropriate data in Cases 1 and 5 are not available.

The slope of the regression line through these points $\left(\Delta \mathrm{Po}_{2}\right)$ $\left.\Delta \mathrm{FIO}_{2}\right)$ is 2.08. Campbell (1960a) has used an approximation of the two-level method of Riley, Cournand, and Donald (1951) to predict the relation between the inspired-oxygen concentration and arterial $\mathrm{Po}_{2}$, but we have not felt justified in this study in making the assumptions necessary to the method and have chosen to derive a purely empirical relationship. In Fig. 5 it will be seen that there is, not surprisingly, variation of response from patient to patient, and these differences are another contributing factor towards the difficulty of predicting the changes in $\mathrm{Po}_{2}$ and $\mathrm{PCO}_{2}$ when oxygen is given.

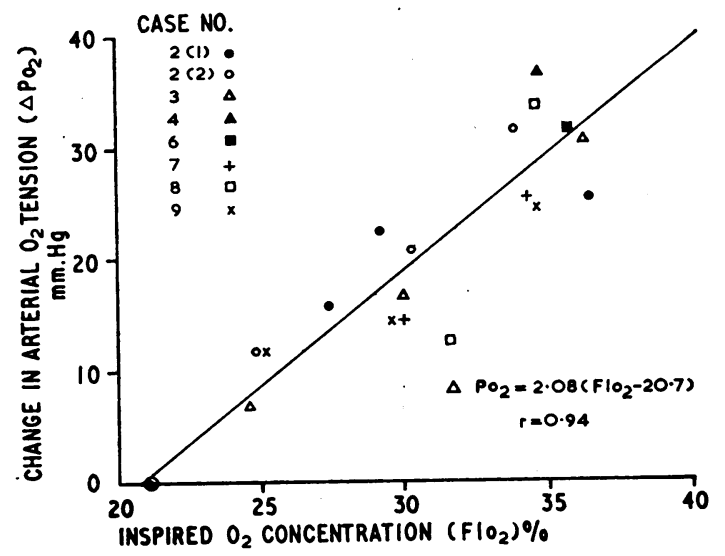

FIG. 5.-Relation between the inspired-oxygen concentrations $\left(\mathrm{FIO}_{2}\right)$ and the increment in arterial oxygen tension $\left(\triangle \mathrm{PO}_{2}\right)$ above that obtaining when breathing air.

\section{Relationship Between the Arterial Oxygen Tension and the Arterial Carbon Dioxide Tension}

In the majority of patients with respiratory failure there is a further rise in $\mathrm{PCO}_{2}$ when oxygen is given. If it is accepted that the rise in $\mathrm{Po}_{2}$ is responsible for the depression of ventilation, then it is clearly of some importance to establish whether

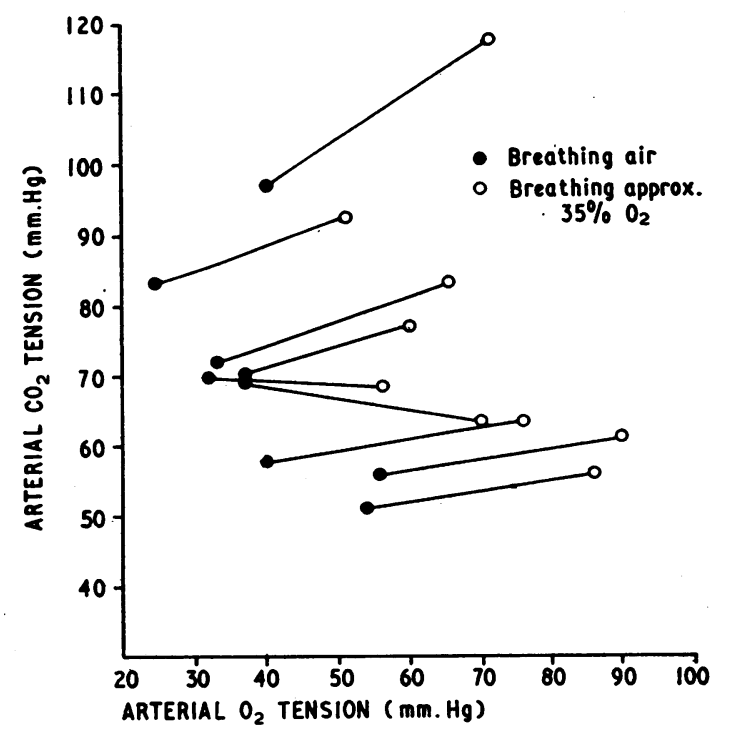

FIG. 6.-Mean arterial carbon dioxide tension $\left(\mathrm{PCO}_{2}\right)$ plotted against mean arterial oxygen tension $\left(\mathrm{PO}_{2}\right)$ when breathing air and after a period of 30 minutes' breathing $35 \%$ oxygen. All studies except Case 5.

there is any relation between the increase in arterial $\mathrm{Po}_{2}\left(\Delta \mathrm{Po}_{2}\right)$ and the increase in arterial $\mathrm{PCO}_{2}\left(\Delta \mathrm{PCO}_{2}\right)$.

Fig. 6 shows the mean $\mathrm{PCO}_{2}$ and $\mathrm{Po}_{2}$ in all cases except Case 5 during the initial period when breathing air and again after a period of at least 30 minutes breathing $35 \%$ oxygen. It will be seen that in two subjects ( 1 and 9) there was no rise in $\mathrm{PCO}_{2}$ as $\mathrm{Po}_{2}$ increased, although both patients evidently had severe respiratory failure; the other patients, however, developed a 
rise in $\mathrm{PCO}_{2}$ as is commonly described. The ratio between the increase in $\mathrm{PCO}_{2}$ and the increase in $\mathrm{PO}_{2}\left(\Delta \mathrm{PcO}_{2} / \Delta \mathrm{PO}_{2}\right)$ is equal to the slope of the lines in Fig. 6 . This ratio appears to increase with increasing $\mathrm{PCO}_{2}$, and the highest value for the ratio was approximately 0.5 (Case 3) when the initial $\mathrm{PCO}_{2}$ was 100 . The exact ratio of $\Delta \mathrm{PCO}_{2} / \Delta \mathrm{Po}_{2}$ is of little value in practical management as these patients are in a changing state, and this ratio cannot be used to predict accurately the changes in $\mathrm{PCO}_{2}$ which will follow changes in $\mathrm{Po}_{2}$ later in the treatment.

Those subjects who decrease their $\mathrm{PCO}_{2}$ and presumably increase their alveolar ventilation when given oxygen are of particular interest. Such patients may be examples of hypoxic but rapidly remediable depression of the respiratory centres. The relation between $\Delta \mathrm{PCO}_{2}$ and $\Delta \mathrm{Po}_{2}$ is clearly of clinical importance, and our results confirm that the danger of further rise in $\mathrm{PCO}_{2}$ during oxygen therapy is greater when the $\mathrm{PCO}_{2}$ is already at high level. The state of carbon-dioxide narcosis may then follow and is usually associated with a severe acidaemia, which of itself may be of even more serious consequence.

\section{Safe Level of Arterial Oxygen Tension}

A rational approach to controlled oxygen therapy in these patients requires that a level of $\mathrm{Po}_{2}$ be found which is high enough to prevent damage from hypoxia, and yet low enough to provide adequate respiratory stimulus, and thereby avoid severe respiratory acidosis. What is the lowest $\mathrm{Po}_{2}$ which is safe in these patients?

Mental function is notoriously sensitive to hypoxia, and the effects in normal subjects are well documented. Boycott and Haldane (1908), experimenting on themselves in a decompression chamber, found a marked decline in mental powers, with loss of judgment and irrational behaviour as their alveolar $\mathrm{Po}_{2}$ fell below 45. Hoffman, Clark, and Brown (1946) and Harboe (1957) found that consciousness is lost at a $\mathrm{Po}_{2}$ of about 30. These results must be applied with caution to patients with chronic respiratory failure. In the first place the subjects in a decompression chamber have a low $\mathrm{PCO}_{2}$ in addition to their hypoxia, for the hypoxia makes them hyperventilate. This low $\mathrm{PCO}_{2}$ causes cerebral vasoconstriction, thereby potentiating the effects of hypoxaemia. The patients considered here have considerable cerebral vasodilatation due to hypercapnia, and this probably has a protective effect by producing a higher cerebraltissue-oxygen tension for a given level of arterial $\mathrm{Po}_{2}$. In addition it is well known that man can acclimatize to low oxygen tensions. For example, West, Lahiri, Gill, Milledge, Pugh, and Ward (1962) demonstrated that mountaineers acclimatized at $19,000 \mathrm{ft}$. $(5,790 \mathrm{~m}$.) could exercise until their $\mathrm{PO}_{2}$ fell' to 25-35, and experienced only severe dyspnoea, without any adverse mental effects.

In our own cases mental changes due to hypoxia could not be clearly distinguished from those due to hypercapnia or acidosis. Hypoxia produces irrational and often aggressive behaviour, whereas hypercapnia leads to progressive drowsiness, but both ultimately cause stupor and finally unconsciousness. The lowest $\mathrm{Po}_{2}$ we obtained was 23 (Case 2); this patient was unconscious on admission but suffered no neurological sequelæ, and his mental faculties were normal on recovery. In a number of other cases the $\mathrm{Po}_{2}$ when breathing air was less than 40 . The $\mathrm{Po}_{2}$ on discharge, when the patients were ambulant, was between 59 and 74 in the six cases where it was measured. We feel that many of these patients are partially acclimatized to hypoxaemia.

Changes in the ST segment and T waves of the E.C.G. were described by Patterson, Clark, and Levy (1942) when patients with myocardial ischaemia breathed low concentrations of oxygen. No such changes were seen in the eight E.C.G.s taken in our cases when the $\mathrm{Po}_{2}$ was between 30 and 50, not even in Case 9 who had evidence of an old myocardial infarction.
Many patients continue to live for some time in a state of chronic respiratory failure, with persistent hypoxaemia and hypercapnia. Baldwin, Cournand, and Richards (1949) found a mean $\mathrm{Po}_{2}$ of 50 (calculated from their values for oxygen saturation and $p \mathrm{H}$ ) in their patients with chronic cor pulmonale. Aber, Bayley, and Bishop (1963) obtained similar results in eight such patients with congestive failure and oedema, but a mean $\mathrm{Po}_{2}$ of 59 in 10 patients with chronic obstructive airways disease without heart failure. Platts, Hammond, and StuartHarris (1960) studied 16 patients who developed congestive failure while under observation; the oxygen saturation before the onset of failure averaged $79 \%$, equivalent to a $\mathrm{Po}_{2}$ of 47 , assuming a $\mathrm{pH}$ of 7.35 . After the onset of failure the mean saturation fell to $68 \%$, equivalent to a $\mathrm{Po}_{2}$ of 38 at the same $p \mathrm{H}$. The patients in all of these studies appeared to be in a relatively stable phase and not suffering from acute exacerbations of chronic respiratory failure.

From this evidence, incomplete though it is, we suggest that a $\mathrm{PO}_{2}$ of 50 will prevent immediate death from hypoxia in these patients, although congestive failure may develop, and we would propose that one aim of controlled oxygen therapy should be to provide a $\mathrm{Po}_{2}$ of at least this level. We have been repeatedly impressed with the difficulty of estimating the level of $\mathrm{Po}_{2}$ from clinical signs, such as the degree of cyanosis or mental condition, and we would emphasize that the only method at present available for ensuring that the $\mathrm{Po}_{2}$ is above 50 is by direct measurements on arterial blood. Furthermore, in any patient with mental changes, due to either hypercapnia or hypoxia, it cannot be safely assumed that the $\mathrm{Po}_{2}$ is over 50 if he is breathing approximately $30 \%$ oxygen (Case 2 (Study-1), Case 7, and Case 9). The safe method is to measure the arterial $\mathrm{Po}_{2}$. In the absence of an oxygen electrode the arterial blood-oxygen saturation is extremely useful, particularly in the range being considered.

\section{Hypercapnia and Respiratory Acidosis}

By definition, respiratory failure is associated with a raised $\mathrm{PCO}_{2}$, which in turn tends to cause a respiratory acidosis. The extent of this acidosis, as measured by the arterial $p \mathrm{H}$, is determined by the buffering capacity of the blood and tissues.

1. $\mathrm{PCO}_{2}$ and $\mathrm{pH}$.- In addition to determination of a safe minimum level of $\mathrm{Po}_{2}$ it is necessary to establish the levels of $\mathrm{PCO}_{2}$ or $\mathrm{pH}$ which can be accepted during controlled oxygen therapy. The mental effects of hypercapnia are well known, these being dominated by drowsiness and coma; hence the term " carbon-dioxide narcosis." Previous workers have found difficulty in establishing at what levels of $\mathrm{PCO}_{2}$ or $\mathrm{pH}$ these changes occur (Comroe et al., 1950 ; Westlake et al., 1955 ; Sieker and Hickam, 1956), and our experience supports this view. For instance, in Case 2 (Study 2) and Case 7 drowsiness was the only feature, despite an initial $\mathrm{PcO}_{2}$ of 70 . Case 9 was mentally normal when the $\mathrm{PcO}_{2}$ was 63 , but she became confused when the $\mathrm{PCO}_{2}$ rose to 100 with oxygen given by a Polymask.

It is difficult to decide the relative importance of $\mathrm{pH}$ or $\mathrm{PCO}_{2}$ levels in determining the danger of respiratory acidosis. The contrast between Cases 3 and 7 in our series impressed upon us the importance of the $\mathrm{pH}$ levels. Both cases suffered from similar degrees of hypercapnia $\left(\mathrm{PCO}_{2} 120\right)$, yet in Case 3, who survived, the lowest $p \mathrm{H}$ was 7.25 and in Case 7, who died, the lowest $\mathrm{pH}$ was 7.06. In three previous studies (Comroe et al., 1950 ; Westlake et al., 1955 ; Sieker and Hickam, 1956) no patient died so long as the $\mathrm{pH}$ remained above 7.25, although Sieker and Hickam report survival in a number of cases where the $p \mathrm{H}$ fell considerably below this level.

2. Buffering Capacity.- The degree of buffering capacity of the blood can be calculated as "buffer base" from the nomogram of Singer and Hastings (1948). This value represents both bicarbonate ion and buffer protein, including haemoglobin. 
Patients who are chronically exposed to high levels of $\mathrm{PCO}_{2}$ increase the renal reabsorption of bicarbonate and thereby increase their buffer base. The rate of bicarbonate reabsorption by the renal tubules can increase by $60 \%$ as the arterial blood $\mathrm{PCO}_{2}$ is raised experimentally from 50 to 100 in the dog (Rector, Seldin, Roberts, and Smith, 1960). This maximal reabsorption rate is achieved only when a given level of hypercapnia is maintained for four days. In our patients there is little change in the level of buffer base after the time of admission, suggesting that the maximal rate of bicarbonate reabsorption had already been reached (Table II).

Gross and Hamilton (1963) have described the difficulty of assessing the absolute level of $\mathrm{PCO}_{2}$ from physical signs, and they conclude that the increase in $\mathrm{PcO}_{2}$ over the patient's normal level when ambulant is of more importance. This "pre-morbid" level is usually not known, but we feel that it can be assumed that the $\mathrm{pH}$ will be above 7.35 in any ambulant patient with chronic respiratory failure. The rise in $\mathrm{PCO}_{2}$ due to an acute exacerbation will therefore be reflected in the fall in $p \mathrm{H}$ below 7.35. Again this supports our view that the arterial $p \mathrm{H}$ is of more immediate prognostic value than the level of $\mathrm{PCO}_{2}$ in the management of these cases.

The importance of the level of buffer base in this context is also illustrated by comparing Case 3 and Case 7. In Case 3 the buffer base was between 61 and $76 \mathrm{mEq} / 1$., well over the normal range of 44 to $52 \mathrm{mEq} / 1$. In Case 7, where the $p H$ fell to 7.06 , the buffer base was only between 42 and $54 \mathrm{mEq} / 1$. In this case the blood urea was $200 \mathrm{mg} . / 100 \mathrm{ml}$., although at necropsy the kidneys were histologically normal. It must be pointed out that the buffer base also depends upon the degree of metabolic acidosis, which can occur owing to the anaerobic production of excess lactate in these hypoxic patients (Huckabee, 1958), in addition to the renal reabsorption of bicarbonate.

It is worth noting that in the series of Sieker and Hickam (1956) the mean $p \mathrm{H}$ was 7.12 , but the mean buffer base remained within the normal range, there being on the average no significant rise to compensate for the acidaemia. The mortality rate was $50 \%$ in this group of patients.

3. Limits of $p H$.-We would suggest that one aim of controlled oxygen therapy should be to maintain the $p \dot{\mathrm{H}}$ over 7.25 . It must be pointed out that arterial blood must be sampled if this measurement is to be made, and that rebreathing methods can only estimate the mixed venous $\mathrm{PCO}_{2}$ (Campbell and Howell, 1960). This method can be invaluable in establishing the diagnosis of respiratory failure, but as it cannot provide information on either the $\mathrm{Po}_{2}$ or the $p \mathrm{H}$ we feel that it is not advisable to rely only on rebreathing methods in the management of severe cases of respiratory failure. In any case where the $\mathrm{PCO}_{2}$ is over 70 by the rebreathing method when the patient is breathing air the $\mathrm{Po}_{2}$ cannot be much more than 30 (Fig. 6), and such a case requires arterial-blood-gas monitoring in order to ensure that controlled oxygen therapy provides a $\mathrm{Po}_{2}$ of at least 50, while the $\mathrm{pH}$ is maintained above 7.25 .

\section{Oxygen Therapy in Respiratory Failure Due to Chronic Bronchitis and Emphysema}

These patients can be treated conservatively with controlled oxygen therapy or by mechanical ventilation with intermittent positive-pressure respiration (I.P.P.R.). From the experience in the studies described above we would propose the following scheme of treatment.

Controlled oxygen therapy can be given with various degrees of sophistication both in administration of the oxygen and in monitoring of the patient's progress.

The simplest treatment requires that only slightly elevated concentrations of oxygen, approximately $30 \%$, be given continuously to any patient in whom an exacerbation of chest infection with cyanosis is present, if that patient is known to suffer from chronic bronchitis and emphysema. The Venturi mask (Campbell, 1960a) or the much cheaper Edinburgh mask (Flenley et al., 1963) will give an oxygen concentration controlled within about $5 \%$ in the range 21 to $35 \%$, and this alone will be adequate for many cases.

If such patients become drowsy, or show other evidence of excessive, carbon-dioxide retention on oxygen therapy, the second line of treatment is indicated. This requires an estimation of the mixed venous $\mathrm{PCO}_{2}$ by the rebreathing method (Campbell and Howell, 1960). This will confirm the diagnosis of respiratory failure and give a reasonable estimate of the arterial $\mathrm{PCO}_{2}$ but it does not measure the degree of acidosis or the adequacy of oxygenation.

For reasons given previously, we would strongly advocate that all three factors- $\mathrm{PCO}_{2}, \mathrm{Po}_{2}$, and $\mathrm{pH}$-should be measured in the arterial blood in any case of severe respiratory failure ; for example, where a "rebreathing $\mathrm{PCO}_{2}$ " is over 70. This then constitutes the third level of sophistication in treatment, with accurate control of the inspired-oxygen concentration and repeated arterial-blood-gas measurements, which are easily obtained if a fine-bore indwelling catheter is introduced into the brachial or radial artery by the Seldinger technique. The lumen of this catheter is kept filled with a weak solution of heparin and the catheter is closed with a tap.

We would propose that the aim of this controlled oxygen therapy should be to maintain a $\mathrm{Po}_{2}$ of at least $50 \mathrm{~mm}$. $\mathrm{Hg}$ without depressing the $\mathrm{pH}$ below 7.25.

Intermittent positive-pressure respiration is indicated in our view if controlled oxygen therapy cannot maintain the arterialblood-gas tensions or $p \mathrm{H}$ at the levels suggested above. In this cautious approach to I.P.P.R. we differ from Massaro, Katz, and Luchsinger (1962), who state " the only safe way to administer oxygen to patients with acute respiratory failure is in conjunction with a mechanical respirator." It is important to realize that I.P.P.R. in these patients, who have severe obstruction of the airways and who often have heart failure, is a very different proposition from that in a young previously fit subject with normal heart and lungs who may suffer from a neurological disorder or thoracic trauma. The cardiac output falls even in normal subjects during I.P.P.R. (Kilburn and Sieker, 1960) and this fall in output can be very serious in patients with cor pulmonale (Roncoroni, Agrest, Roehr, and Grzesko, 1962). Sieker and Hickam (1956) had a mortality of $50 \%$ in their patients with very severe respiratory acidosis despite the use of I.P.P.R.

Tracheostomy is often advocated in the treatment of respiratory failure. In our view this procedure is required in two circumstances. Firstly, it is necessary when obstruction of the major airways with secretions recurs despite repeated physiotherapy or bronchoscopy. Tracheostomy allows more adequate trachial toilet in the patient who will not cough. In the second place, of course, tracheostomy is necessary before instituting I.P.P.R. with a cuffed tracheostomy tube.

Other measures required in these cases include control of infection with antibiotics, control of heart failure with digoxin and diuretics, the avoidance of sedatives (unless the patient is on a respirator), and the use of respiratory stimulants.

In summary, the management of these cases can be viewed as a therapeutic crescendo, from simple administration of slightly raised oxygen concentrations to full-scale repeated arterial blood sampling and close control of the inspired-oxygen concentration, with resort to I.P.P.R. if the suggested limits cannot be obtained by conservative measures.

The measurement of arterial $\mathrm{Po}_{2}, \mathrm{PcO}_{2}$, and $\mathrm{pH}$ has until recently been the province of specialized departments, but a strong case can now be made for the ready availability of such methods and of technical staff trained in their use. The insertion of a small-bore catheter into a peripheral artery is a simple procedure, and complications are extremely rare. The recent development of electrode methods for determining blood-gas tensions should be exploited more fully in the clinical field. 
These measurements can now be made by a well-trained technician, the apparatus being mounted on a trolley for use in the ward area. While resistance to such arterial blood monitoring undoubtedly exists, it should be remembered that largebore arterial catheters are now often used for radiological investigations in many conditions where life is not immediately threatened.

It is universally accepted that severe metabolic emergencies such as diabetic coma or acute renal failure require precise biochemical monitoring, and a different standard of observation and treatment for patients with severe respiratory failure is no longer acceptable. Both diabetic coma and advanced respiratory failure are serious emergencies which are nevertheless reversible in a large number of cases. Both emergencies require constant attention by an experienced physician supported by technical staff, and both demand frequent estimation of the appropriate blood chemistry over a number of hours or even days until a safe degree of recovery is assured.

\section{Summary}

Ten detailed studies of respiratory failure secondary to an acute exacerbation of chronic bronchitis are reported. The response of the patients to precisely defined variations in the inspired-oxygen concentration was studied by frequent analysis of the $\mathrm{Po}_{2}, \mathrm{PCO}_{2}$, and $\mathrm{pH}$ of the arterial blood, sampled from an indwelling catheter.

A wide variation in the response of the patients to oxygen was found and some of the factors which contribute to these variations have been investigated. These include: $(a)$ the degree of control of the inspired-oxygen concentration, $(b)$ the varying relation between the inspired-oxygen concentration and the arterial $\mathrm{PO}_{2}$, and (c) the varying relation between changes in arterial $\mathrm{Po}_{2}$ and changes in the $\mathrm{PCO}_{2}$.

It is proposed that the aim of conservative management by controlled-oxygen therapy in these cases should be to maintain an arterial $\mathrm{Po}_{2}$ of at least 50, without allowing the $p \mathrm{H}$ to fall below 7.25. A low arterial $\mathrm{pH}$ is thought to be of more value in assessing the severity of the condition than is the level of the arterial $\mathrm{PCO}_{2}$. A $\mathrm{PCO}_{2}$ of 70 or more when breathing air suggests that severe respiratory acidosis is almost certain to occur if oxygen is given in high concentration.

Accurate control of the inspired-oxygen concentration has proved of great value even in severe cases of respiratory failure, for by this means adequate relief of hypoxia can be obtained without the production of severe respiratory acidosis. It is suggested that control of the inspired concentration within $5 \%$ in the 21 to $35 \%$ range is required, and that higher concentrations of oxygen may still be dangerous for at least three days after the start of controlled-oxygen therapy even if the response to this treatment is satisfactory. Oxygen therapy may well be required for at least one week.

Tracheostomy and mechanical ventilation are proposed as a second line of treatment if controlled oxygen therapy with antibiotics, bronchodilators, and respiratory stimulants cannot maintain an arterial $\mathrm{Po}_{2}$ over 50 without depressing the $p \mathrm{H}$ below 7.25 .

A plea is made for a higher general standard of quantitative observation and treatment in respiratory failure. The levels of oxygen being administered should be known and the response in terms of arterial $\mathrm{Po}_{2}, \mathrm{PCO}_{2}$, and $\mathrm{pH}$ should be accurately determined.

One of us (D.C.F.) was supported by a grant from the Medical Research Council, and one of us (D.C.S.H.) was supported by the Scottish Home and Health Department.

\section{REFERENCES}

Aber, G. M., Bayley, T. J., and Bishop, J. M. (1963). Clin. Sci., 25, 159.

Baldwin, E. de F., Cournand, A., and Richards, D. W. (1949). Medicine (Baltimore), 28, 201.

Barach, A. L. (1938). Ann. intern. Med., 12, 454.

Bernéus, B., Carlsten, A., Holmgren, A., and Seldinger, S. I. (1954). Scand. F. clin. Lab. Invest., 6, 217.

Bishop, J. M., and Pincock, A. C. (1959). F. Physiol. (Lond.), 145, $20 \mathrm{P}$.

Boycott, A. E., and Haldane, J. S. (1908). Ibid, 37, 355.

Campbell, E. J. M. (1960a). Lancet, 2, 10.

- (1960b). Ibid., 2, 12.

- and Howell, J. B. L. (1960). Brit. med. F., 1, 458.

Comroe, J. H., Bahnson, E. R., and Coates, E. O. (1950). F. Amer. med. Ass., 143, 1044.

Donald, K. W. (1949). Lancet, 2, 1056.

(1953). Ibid., 1, 495.

Flenley, D. C., Hutchison, D. C. S., and Donald, K. W. (1963). Brit. med. $7 ., 2,1081$.

Gross, N. J., and Hamilton, J. D. (1963). Ibid., 2, 1096.

Harboe, M. (1957). Acta physiol. scand., 40, 248.

Hoffman, C. E., Clark, R. T., and Brown, E. B. (1946). Amer. F. Physiol., $145,685$.

Huckabee, W. E. (1958). F. clin. Invest., 37, 264.

Kilburn, K. H., and Sieker, H. O. (1960). Circulat. Res., 8, 660.

Laws, J. W., and Heard, B. E. (1962). Brit. F. Radiol., 35, 750.

Massaro, D. J., Katz, S., and Luchsinger, P. C. (1962). Brit. med. F., 2, 627.

Meneely, G. R., and Kaltreider, N. L. (1941). Proc. Soc. exp. Biol. (N.Y.), 46, 266.

Needham, C. D., Rogan, M. C., and McDonald, I. (1954). Thorax, 9, 313.

Patterson, J. E., Clark, T. W., and Levy, R. L. (1942). Amer. Heart f., 23, 837.

Platts, M. M., Hammond, J. D. S., and Stuart-Harris, C. H. (1960). Quart. F. Med., 29, 559.

Rector, F. C., Seldin, D. W., Roberts, A. D., and Smith, J. S. (1960). f. clin. Invest., 39, 1706.

Riley, R. L., Cournand, A., and Donald, K. W. (1951). F. appl. Physiol., 4, 102 .

Roncoroni, A. J., Agrest, A., Roehr, E., and Grzesko, S. (1962). Amer. Heart $\mathcal{F}, 64,207$.

Severinghaus, J. W. (1958). In Handbook of Respiration, edited by D. S. Dittmer and R. M. Grebe, p. 73. Saunders, Philadelphia. and Bradley, A. F. (1958). F. appl. Physiol., 13, 515.

Sieker, H. O., and Hickam, J. B. (1956). Medicine (Baltimore), 35, 389. Singer, R. B., and Hastings, A. B. (1948). Ibid., 27, 223.

West, J. B., Lahiri, S., Gill, M. B., Milledge, J. S., Pugh, L. G. C. E., and Ward, M. P.'(1962). f. appl. Physiol., 17, 617 .

Westlake, E. K., Simpson, T., and Kaye, M. (1955). Quart. F. Med., 24, 155 . 